\title{
The Educational Culture of Muhammadiyah in North Sumatra
}

\author{
Dr. Afrahul Fadhila Daulai, $\mathrm{MA}^{1}$ \\ ${ }^{I}$ Ph.D Student at State Islamic University of North Sumatra (UINSU), Medan \\ ${ }^{1}$ Lecturer at Da'wah Faculty, State Islamic University of North Sumatra (UINSU), Medan
}

\begin{abstract}
The purpose of this study is to determine the cultures of Muhammadiyah education in North Sumatra which covers. (1) Embedding the Muhammadiyah ideology in schools (2). The use of Muhammadiyah symbols (3) Educational environment: faith, knowledge and charity. (4) Education curriculum; amaliyah, scientific deeds or scholar's intellectuality and intellectual scholars. (5). Work ethic; those who planted he who harvest. (6) The organization committee that is PersyarikatanMuhammadiyah.

This type of research is qualitative which tries to describe the results of the research in the form of written words that are the result of in-depth interviews, participatory observation and documentary studies. Meanwhile the approach used is a descriptive approach. The method of collecting data includes in-depth interviews, participatory observation and documentary studies. Data analysis technique is data reduction, data presentation and verification of data. Meanwhile the technique of checking the data validity is carried out by four criteria; level of confidence, transition, dependability and certainty or objectivity.
\end{abstract}

Keywords: educational culture; Muhammadiyah; symbol; da'wah

\section{INTRODUCTION}

Muhammadiyah as the largest and modern Islamic organization in North Sumatra has many charitable efforts in education which are scattered in the municipality/city, district, sub district to the remote villages which are inaccessible transportation; cars, motorcycles and public transportation. According to data from Regional Chairman of Muhammadiyah North Sumatra (PWMSU), 2015, it has 364 schools, with the details, 25 BustanulAthfal, 107 primary schools (SD), 12 Madrasah Ibtidaiya (MI), 92 Madrasah Diniyah Al-Awwaliyah (MDA), 51 Muhammadiyah junior high Schools (SMPM), 26 Madrasah Tsanawiyah (MTsM), 11 Madrasah 'Aliyah Muhammadiyah (MAM), 20 Senior high schools (SMA), 15 Vocational senior high school (SMK), 5 colleges which cover UniversitasMuhammadiyah Sumatera Utara (UMSU) in Medan City, Universitas Muhammadiyah Tapanuli Selatan (UMTS) in Padang Sidempuan, Sekolah Tinggi Ilmu Tarbiyah in Sibolga, Central Tapanuli, Sekolah Tinggi Ilmu Hukum (STHI) and Sekolah Tinggi Ilmu Ekonomi (STIE) in Asahan Municipality (Statistic Data PWMSU year 2015). In general, these schools are located in a complex which is called perguruanMuhammadiyah except complex the college. From a management point it is more easily to manage professionally and the students who graduate will have no difficulty in finding another school and choose Muhammadiyahschool according to the level.

All Muhammadiyah schools mentioned above have educational cultures which are the trademark of its education. The educational culture means the ideology or ideas, customs, norms, values, language, art and science. Kuntowijoyo says that culture is the idea, customs, symbols and values which influence the people's lives (Kuntowijoyo: 2001: xi). Koentjaraningrat says that culture is the whole system, the work and creation of human in the frame of a society life which becomes the human owns to learn. The elements of culture include; language, knowledge systems, social organization, systems of knowledge and technology, livelihood systems, religion and the arts (Koentjaraningrat, 2000: 203-204).

Based on the research results (AfrahulFadhilaDaulay: 2016: 35), it is found that there are six forms of educational culture of Muhammadiyah in North Sumatra. (1). Embedding the Muhammadiyah ideology in schools (2). The use of Muhammadiyah symbols (3). Educational environment; faith, knowledge and charity. (4). Education curriculum; amaliyah (good deeds), scientific deeds or scholars intellectuality and intellectual scholars. (5). Work ethic; those who planted he who harvest. (6). The organization committee that is PersyarikatanMuhammadiyah.These six forms of educational culture above are popular and grounded in the midst of society, meaning the stakeholders of education are quite easy to recognize and distinguish the identity between Muhammadiyah education and non Muhammadiyah education. Especially with the educational organization of NahdlatulUlama (NU) and Al Jam'iyatulWashliyah which are more focused on strengthening the traditions and rites of the religion. In Zamroni;s opinion, the greatness of Muhammadiyah education is clearly identified although now Muhammadiyah education is more prominent inside it the national education system (Zamroni, 2014: 72). 


\section{METHODOLOGY}

This research is a qualitative study which tries to describe the results of research in the form of written words which are the result of in-depth interviews, participatory observation and documentary studies. Lexi J. Moleong says qualitative research is a research that intends to understand the social phenomenon of what is experienced by the subject of the study such as the behavior, perception, motivation, and the action as a whole which is described in the form of words and language in a natural context by using natural methods (Moleong, 2012: 6). Meanwhile the approach used is descriptive approach. The sources of data obtained from the provincial chairman of Muhammadiyah (PWMSU), regional chairman of Muhammadiyah (PDM), Branch chairman, Sub Branch chairman, Assembly of Elementary and Secondary Education and the head masters of Muhammadiyah schools.

The methods of data collection used in-depth interviews, participatory observation and documentary studies; past record, in the form of text, images and monumental works. The technique of data analysis used data reduction, data presentation and verification of conclusion. Data reduction means summarizing, sorting things considered primary, seeking themes, patterns and discarding the things which are considered unimportant. Data presentation means in the form of a brief description or written words, the relationship between categories and narrative. Meanwhile verification of conclusions means the research conclusions should be able to answer the research objectives. The technique of checking the data validity is carried out by four criteria; (1) Level of credibility is checking and testing the validity of the data before so it is not doubted its accuracy. (2) Transition which means seeking and collecting empirical facts about the common context. (3) The dependence which means reconfirming the credible source. (4) Certainty or objectivity which means the truth obtained can be tested by others.

\section{DISCUSSION}

The cultures of Muhammadiyah education form in North Sumatra are first embedding the Muhammadiyah ideology in schools. Ideology is the ideas or thoughts, values which have direction and purpose. Ahmad Syafii (2000: 108) says that ideology is a set of ideas to change the reality which is considered not feasible for the needs of a group of people. In view of Muhammadiyah, ideology is the belief and ideals of Muhammadiyah life $(\mathrm{MKCH})$ which involves (a). Muhammadiyah is the Islamic movement which has aspiration and work towards the true Islamic community based on the Qur'an and Sunnah. (b). Muhammadiyah has the belief that Islam is the religion of monotheism revealed since Adam AS to the Prophet Muhammad PBUH as the final prophet. (c). Muhammadiyah in practicing the teachings of Islam based on the Qur'an and Sunnah. (d). Muhammadiyah works optimally for the realization of faith, worship, morals and muamalah.

In an effort to realize ideals of Muhammadiyah life as mentioned above, in Muhammadiyah schools from primary to high school (SMA) or equivalent Al-Islam and Kemuhammadiyahan (Al-Islam and Muhammadiyah teachings) are taught. In college the subject is named as Al-Islam which is taught in each odd and even semester at every faculty and becomes one of constions to pass any degree. The purpose of Al-Islam and Kemuhammadiyahan in schools is to impart the knowledge of religion in Muhammadiyah version either from Qur'an, faith, worship, morals and muamalah. After the students graduate they are expected to become cadres and preachers of Muhammadiyah in the environment or society.

In the eyes of students, Al-Islam and Kemuhammadiyahan is considered as positive because it provides a more complete understanding of the religions. In the field of theology taught about the importance of purifying Tawheed and should not be mixed with any Takhayul, Bid'ah (heresy) and Khurafat (TBC). Takhayul (superstition) is the belief in things that are considered sacred, bringing blessings and help in life. Bid'ah (heresy) is any forced dees and there is no source in the Qur'an and Sunnah, but called as the words and deeds of the prophet. Khurafat (traditional superstition) is the belief in the legends, fairy tales, stories and the accuracy is questionable and contrary to Islamic beliefs. For examples, tepungtawar (scaterring the flour), and upah-upah (giving the spirit) at a wedding party, child birth and departure of pilgrims to Mecca. This act is a Hinduism culture and adopted by most Muslims. In the field of worship, the students are taught the pattern of worship that was practiced by the Prophet Muhammad PBUH. In prayer for instance it is required to read iftitah prayer ieAllahummaba'idBainiwakhatayayaBaina. Reading Bismillahirrahmanirrahim is not obliged, rukuk (bowing) and sujud (kneeling and head touches the ground) prayer read Subhana kallahumma rabbana wa bihamdika allahummaghfirli. After praying, there is no together zikir (remembrance to Allah) but prayer alone, the reason is the jamaah's request to Allah SWT is not the same. Similarly, the implementation of 11 cycles tarawih prayers, Eid prayer and Eid al-Adha prayer in the field. The reference understanding of worship is Himpunan Putusan Tarjih Muhammadiyah (HPTM). In morals, they are taught the finer and reprehensible virtues. Virtue means a picture of one's soul, if his action is good then it is a picture of his soul and on the contrary if his deeds are bad then that is picture of his soul.

In Muamalah (activities involve others) which means that every follower of Muhammadiyah is aware of himself as a perfect servant of Allah, given the mind and soul, to be inheritors on earth, looked at life as a temporary pleasures that must be achieved with the best and cannot forget the hereafter. In family life means 
making the family as the main pillar of community life, as a place of socialization and religious values. Therefore, it is the duty of every member of the family to realize sakinah (happiness), mawaddah (love), warahmah (mercy) family (Muhammadiyah, Yogyakarta, 2008: 60-63).

Besides constructing of Muhammadiyah ideology in terms of religion, ideological construction is also held in the form of first, the establishment of IPM organization (Muhamamdiyah Student Association). All the students are required to become the members. The activities include religion studies, learning to read the AlQuran, training of cadre leadership, training of prayer imam, Friday sermon, and Ramadan Safari to Taqwa Muhammadiyah mosques. Second is setting up Hizbul Wathan (HW) scouts and Tapak Suci Muhammadiyah (TSM), a kind of martial art. HW activities include scouts, camp, and drum band. Meanwhile TSM activities are pencak silat, karate, and taekwondo.

The third is the use of Muhammadiyah symbols. In front of the school gates there are written Perguruan Muhammadiyah, bearing the bright white and shining sun with the 12 lights radiating out into the world. In the midst of the sun it is written Muhammadiyah in Arabic alphabet, at the circular sun there is syahadatain; Asyhadu alla ilaha illallah wa asyhadu anna Muhammmadarasulullah. The Syahadatain sentence lies at the foundation of fresh green color that symbolizes the fertility and peace.

The use of Muhammadiyah symbol means the followers of the Prophet Muhammad PBUH as a messenger of Allah and the last prophet. The aim is to gather the Muslims' power and follow his all treatise, his history struggles, his good examples and practice his sunnah (traditions) so that they really became devout and perfect Muslims.

The symbol of the sun means the sun is one of Allah's creations that shines every morning, and is particularly useful for the survival of all Allah's creatures without any exception. Without sunlight, the world will be dark and frozen, all living things will not be able to live. Muhammadiyah is described as movement and its advantages are like the shining sun that is providing the light in the form of belief that there is no god but Allah and Muhammad is the messenger of Allah. The belief cannot be denied except the man who is blind his mind and heart. The sun shines 12 means the followers of Muhammadiyah wherever they are must be able to illuminate the human being to the way of Islam as a revelation religion (faith). To realize the above symbol of Muhammadiyah in all mosques, mushallas, educational institutions (schools), orphanages, offices, preacher's platform, books, magazines, newsletters, letterhead, letters of Muhammadiyah decrees, congress, tanwir conference, tanfiz, assemblies, institutions, and the flag of Muhammadiyah. The use of Muhammadiyah symbol has functions to demonstrate the characteristics of Muihammadiyah and more easily recognizable as organization which calls itself the movement of Islamic da'wah amar ma'ruf and nahi mungkar.

The third, the educational environment includes three major aspects, namely faith, knowledge, and charity. Faith means trust which is not only spoken but also verbally, confessed in heart but practiced it with the limbs. Muhammadiyah education should be based on a solid foundation of faith, without the foundation of faith it is feared that the administrators, educators, staff, followers and sympathizers will be fragile in Muhammadiyah's soul and more prioritize the personal and group interests in the organization. To realize the foundation of faith, then in each Muhammadiyah education Taqwa mosques and mushalla are built as the center of da'wahactivity. Because in Muihammadiyah's view that through the mosque it is easier to build the faith, worship and build the learners' noble characters. When it is related to the da'wah of the Prophet Muhammad PBUH in the period of Mecca and Medina, the priority is the construction of mosques. Muhammadiyah position is modeled the prophet's da'wah movement which started from the mosque and then moved into other fields.

Knowledge is something systematically arranged according to scientific methods. The knowledge meant in Muhammadiyah education is the knowledge related to religious sciences and general knowledge included in the curriculum. Therefore, it is no surprise that the curriculum is symbolized with knowledge, the mosque symbolized with faith. The teachings of religion knowledge and general science education are the characteristics of Muhammadiyah. When K.H. Ahmad Dahlan reformed the Islamic education in Indonesia, the main his accomplishment was combining the teaching of religions sciences and general science. Later specifically the religion studies focused on the subjects of Al-Islam and Kemuhammadiyahan.

Muhammadiyah education which is knowledge-oriented is expected that learners are not only experts in the field of religion but also masters in science generally. The demand on the mastery of both disciplines has recently become a necessity because of the rapid social changes, advances in science and technology that cannot be denied. Future minded schools, educators, visionary leaders of Muhammadiyah who always try to master both discipline. It is important the both combining sciences. On one side, it is to form the Islamic learners and educators who are not secular and not anti to the progress. There is a balance between intellect and spiritual. Modern humans should ideally have both intelligences. In Western education world, it prioritizes the intellectual intelligence and ignores spiritual intelligence.

Komaruddin Hidayat says that the Western world is developed in intellectual intelligence is lack of spiritual intelligence aspect. One of the most prominent characteristics in modern society is the aggressive attitude towards the advancement of science. Driven by the various achievements in science and technology, 
modern society seeks to remove the myth of the sacred universe. All are subject to the power of science and technology that pivot on rationality. The reality of the universe which in the religious doctrine is called the veil of metaphysics and the greatness of Allah SWT, now is only understood as autonomous object that has nothing to do with the greatness of Allah SWT. The universe is understood as a giant clock that its short needle and long hands have already been played, while the position of God has retired and has nothing to do with the life of the world (Majid, 2000: 97). In fact, they forget that Allah SWT never slumbers nor sleep (Surah Al-Baqarah: 255). In this regard Allah says

"Allah there is no deity except Him. The Ever Living, The Sustainer of (all) existence. Neither drowsiness overtakes Him nor sleeps. To Him belongs whatever is in the heavens and whatever is on the earth. Who is it that can intercede with Him except by His permission? (presently) before them and what will be after them, and they encompass not a thing of His knowledge except for what He wills. His Kursi extends over the heavens and the earth, and their preservation tires Him not. And He is the Most High, The Most Great."

Furthermore, the material world is understood separately with immaterial. The material can be filled with an intellectual intelligence while immaterial is deemed as vision. When man separates the material with the immaterial world here seems people do not need Allah's greatness in solving the problems of life. Fully believe in the power of rational. Until now the paradigm is still very dominant in the life of modern society. Therefore, there is a criticism of the achieved progress that is advanced in common sense but poor in spiritual, the spirit of Muhamamdiyah education precisely combines two strengths of intellectual spiritual senses. In reaching the charity domain, Muhammadiyah education is not only focus on the faith domain, and science but also in charity. The form of charity is realized in extracurricular activities at school such as scouting of Hizbul Wathan (HW), TapakSuciMuhammadiyah (TSM), sports and art. This charity for students is considered quite important to protect themselves from immoral behavior and impolite behavior in family, school and community. The fourth is the curriculum; amaliah eduation, scientific amal, scholar intellectuality and intellectual scholars. Muhammadiyah education curriculum has two main features, firstly, religion-based curriculum. Secondly is general knowledge-based curriculum. This is called a blend of amaliah education and educational good deeds. Both are not possible be separated, they are interrelated. In Western education both are clearly separated so what stands out is a scientific amal.

Similarly, the merger of the two the curriculum means creates intellectual scholars who not only mastering the religion knowledge but also general science. Meanwhile intellectual scholars means more prevalent in intellectual ability. To generate the intellectual scholars and scholars intellectuality, Muhammadiyah integrates the religion education with general education. The culture of education adopted by Muhammadiyah, creates a lot of criticisms and comments from the scholars, educational experts and activists that Muhammadiyah education is less prominent in characteristic of religion but it is more dominant intellectual in intelligence. Such criticism might be true, if it is associated with Muhamamdiyah pesantren (Islamic boarding school) there are not many but more in the form of modern education. So far there are still a lot of opinions that pesantren produces more cadres of modern school scholars while the modern schools tend to the intelligence. This view has some truths, but do not forget that in Muhammadiyah there is an assembly which takes care of the scholars that is Majlis Tarjih, it may be less optimal in performing its tasks and functions.

The fifth is work ethic; 'who is planning then he who is harvesting'. The purpose of this culture is an effort to motivate the students to learn seriously and the success achieved is not separated from seriousness. There is no leader in this world that successfully performs the purity and the reformation without any purification and determination. K.H. Ahmad Dahlan, Ki HajarDewantara, General Sudirman, Soeharto, Hamka, and others achieved their success because of their life motivations to promote the Indonesian nation.

The above culture is still inflamed in Muhammadiyah schools so that the educators, students, and the administrators of Muhammadiyah always implant the reforming of implementation in education, management, curriculum, funding for education, infrastructure and facilities. Someday it will produce or harvest not only addressed to schools but also to society in general. The sixth is the implementation organization in this case is Persyarikatan Muhammadiyah. The motto of this organization is live in Muhammadiyah way and do not search for life in Muhammadiyah, Muhammadiyah schools grow and develop from the bottom not from the top to the bottom. Here lies the independence of educational institutions and do not want to be exploited for political purposes but purely for educational purposes in order to participate in educating the nation and free from foolishness and backwardness.

To realize the six Muhammadiyah education cultures today is not an easy task, it is not as easy as flipping through the palm of the hand, especially there is a saying that it is true that the quantity of Muhammadiyah schools are all over the country, but on the other side it is lack of quality. The school policy is too centralized and giving less space for the headmasters to create or innovate. The education assemblies are less optimal in performing their duties; they are not equal between their duties and their positions. The headmasters' competences are insufficient and the payment of the teachers is not standard and also there is no regulation of teachers among Muhammadiyah schools. Education management reform means that to renew the 
education management in Persyarikatan Muhammadiyah. The reforms are first, giving a wider opportunity to the Muhammadiyah schools from primary schools - senior high schools to colleges to take decisions related to education policy. The policy here is the policy of the School Based Management (SBM). Second is giving a wider opportunity to the public to participate in the school management. Third a developing school management that supports the best achievement. Fourth, the role of Muhammadiyah leaders at every level must have clear roles in organizing the schools. Muhammadiyah education structure which is centralized is considered less suitable. It is more appropriately to give it to the municipalities, regions, branches and twigs. Fifth, the educators in Muhammadiyah schools must be prepared and planned carefully. Sixth, Muhammadiyah education needs to be reorganized in order to realize the culture of education which was designed by K.H. Ahmad Dahlan as the founder.

\section{CONCLUSION}

Muhammadiyah as da'wah Islamic movement based on amar ma'ruf and nahi mungkar as well as tajdid (revival) has six educational culture in North Sumatra. (1). Embedding the Muhammadiyah ideology in schools (2). The use of Muhammadiyah symbols (3). Educational environment; faith, knowledge and charity. (4). Education curriculum; amaliyah, scientific deeds or scholars intellectuality and intellectual scholars. (5). Work ethic; those who planted he who harvest. (6). The organization committee that is Persyarikatan Muhammadiyah. All those educational cultures are the characteristics of Muhammadiyah education.

[1] Alquran al-Karim

\section{REFERENCES}

[2] Ali, Mohammad. (2010). Reinvensi Pendidikan Muhammadiyah. Jakarta: Al-WasatBungin,Burhan.2007. Penelitian Kualitatif Komunikasi, Ekonomi, Kebijakan Publik dan Ilmu Sosial Lainnya. Jakarta; Kencana.

[3] Koentjaraningrat, 2000. Pengantar Ilmu Antropologi. Jakarta: Rineka Cipta.

[4] Kuntowijoyo, 2001. Muslim Tanpa Mesjid. Bandung: Mizan.

[5] Madjid, Nurcholish. 2000. Kehampaan Spiritual Masyarakat Modern. Jakarta: Mediacita.

[6] Maarif, Ahmad Syafii, 2000. Dalam Rekonstruksi Gerakan Muhammadiyah Era MultiPeradaban. Yogyakarta: UII Press.

[7] Moleong, Lexi J.2012. Metodologi Penelitian Kualitatif. Bandung: Rosdakarya.

[8] Mu'arif.2005. Meruwat Muhammadiyah Kritik Seabad Pembaruan Islam di Indonesia. Yogyakarta: Nuansa Media.

[9] Nashir, Haedar. 2010. Muhammadiyah Gerakan Pembaruan.Yogyakarta: Suara Muhammadiyah.

[10] Pimpinan Pusat Muhammadiyah. 2008. Pedoman Islami Warga Muhammadiyah. Yogyakarta: Suara Muhammadiyah.

[11] Siddik, Dja'far. 2007. Pendidikan Muhammadiyah Perspektif Ilmu Pendidikan. Bandung: Pustaka Media.

[12] Zamroni. 2014. Percikan Pemikiran Pendidikan Muhammadiyah. Yogyakarta: Penerbit Ombak. 